\title{
An Analysis of the Legislative Developments of the Dispute Resolution Council Laws
}

\author{
Mehri Vazneh ${ }^{1}$, Hamidreza Salimian Rizi ${ }^{2}$ \\ ${ }^{1,2}$ Department of Law, Naragh Branch, Islamic Azad University, Naragh, Iran
}

\begin{abstract}
According to the Constitution, the Judiciary is the competent authority to deal with claims in a broad and general sense. However, due to different reasons, litigation has not been limited to the Judiciary, and other institutions have emerged to deal with certain specific claims. One of these institutions is the Dispute Resolution Council (DRC), which has been established in recent years to deal with claims based on the citizen participation strategy. This council was legally established after the approval of Article 189 in the Third Economic, Social and Cultural Development Plan Code.Findings of this study revealed that law of the DRC has undergone several innovations and changes in the DRC Code of 2015, including: a change in the number of councilors and its top officials and the possibility of using retired judges as the council judges, that neither the DRC nor its judge is allowed to issue any decree; they can only issue corrective reports, and the implicit acceptance of the council's competence owing to lack of citation in the first session is just limited to Article 8 and the competence of the council rather than the judge. Although, the law remains silent about the DRCs of rural areas, its competence has been limited in Note 2 of Article 9 to peace and compromise.
\end{abstract}

Keywords: DRCs, DRC's regulations, principles of litigation, quasi-judiciary institution

\section{1- Introduction}

According to the Constitution, the Judiciary Power is in charge of dealing with trials, and no other institution can do so. However, the jam in the courts and the related problems led to the prediction of DRCs in Article 189 of the Development Plan as an attempt to decrease the number of litigations in courts. Subsequently, the cabinet approved its rules of procedure, and it was published in an official newspaper on $7^{\text {th }}$ of August, 2002, and is presently executed throughout the country.

In order to understand the rationale behind the establishment of DRCs, we need to take a brief look at Article 189 in the Third Economic, Social and Cultural Development Plan Code approved by the Islamic Consultative Assembly on $5^{\text {th }}$ of April, 2000. 
"As an attempt to reduce the burden of the courts, to ease the litigants, increase public participation, the DRC is established to resolve local disputes as well as issues which are not judicial in nature, or which have a less complex judicial nature".

As inferred from this article, reduction of the burden of courts and enhancement of public participation are the rationales behind the very existence of DRCs. Therefore, one of the goals of establishment of the DRC is to reduce the number of litigations and arrive at a compromise between the parties to a dispute.

Although the statistics indicate a decrease in the number of people's referral to judicial courts, this contradicts one of the explicit principles of the Constitution. Article 34 of the Constitution recognizes people's right to refer to courts, but the judicial courts have been incapacitated in Article 189 of the Economic, Social and Cultural Development Plan Code approved by Islamic Consultative Assembly in $5^{\text {th }}$ of April, 2000 and section 4 of Article 1 of its Rules of Procedure. In order to practice in such a way that this article does not contradict the Constitution, the parties should agree rather than forced as to where to refer for their claims.

Regarding the legislative developments of the DRC, it should be asserted that the most important disadvantages of this law include the extended range of DRC membership qualifications and that the objected judgments should be dealt with again in public courts; both of which are time consuming for the public and legal courts and parties to the dispute; moreover, if they refuse to deal with a specialized case, they should act as a referee or a consolidate judge. Even in case a compromise is reached, the members need to have the expertise to ensure that they do not oppress the rights of the parties.

It seems necessary to mention, despite the fact that DRCs resolve nearly one-third of judicial cases, that they are not known very well and sometimes regarded as an unnecessary institution that lacks executive power. However, all these views are incomplete and inadequate; in fact, DRCs do own executive power and are part of the Judiciary.

According to the Principles of the Constitution of the Islamic Republic of Iran, the Judiciary is in charge of Resolution of disputes and claims. Currently, some claims are resolved by the DRCs, so, it is essential to determine the status of this council in the Judiciary system.

Unfortunately, the goals of the DRC are often regarded subjective judgments, which lead to false and illegal expectations of these councils. 
In addition, non-members often make comments and decisions about DRCs while they do not have a precise and accurate knowledge about them. Even in some cases such as advisory opinions of the judicial departments or alike, their specialized opinions are combined with managerial attitudes, which leads to conflicts among themselves or with relevant laws.

In order to get rid of bureaucracy and speed up legal processes and in order for the judicial system to have more and better efficiency, we have no alternative, but to adapt ourselves with the social developments of the current century, and the Third Economic, Social and Cultural Development Plan Code has taken the first step towards it.

\section{Literature Review}

No research has dealt with the legislative developments of the DRC yet. However, this code shares a lot with Article 189 of the Third Economic, Social and Cultural Development Plan Code and its executive regulations, including the following:

1) A Handbook on Practical Proceedings of the DRC, by Gholamreza Movahedian, Deputy Head of Qom, Ghaza Publication, 2004.

This book has just dealt with the practical aspects of proceedings and is a practical guide for the council processes. It has not dealt with an analysis and critique of the legal issues. Moreover, the content of this book is in accordance with the approved law of 2008.

2. Hamidian, H, A Comparative study of Dispute Resolution Councils, Dadgostar Publication, First edition, 2010.

This book deals only with the positive aspects of the issue and the strengths rather than the weaknesses of the DRC. It has been written in accordance with the DRC Act of 2008 and it does not include the strengths and weaknesses of the present Act approved in 2015.

3. Farnam, Hakimeh, Principles of Fair Proceedings in the Laws and Regulations of the DRC, Farnam Publication, First edition, 2013.

This book has also dealt with the principles of the proceedings, such as litigious proceedings, equality of arms, etc., and the author has just criticized the international documents descriptively.

3. An Analysis and critique of legislative developments of the DRCs regarding the structure and composition of the council, selection of members, and recusation 


\subsection{An Analysis and critique of legislative developments regarding the structure of the council}

Formation of a new council, or maintenance or dissolution of existing councils are possible when it is proposed by the chief justice of the province to the head of the Judiciary.

According to Article 2 of the DRC Act approved in 2008, it is the Council Affairs Center that is in charge of planning and monitoring the performance of the councils. The head of the center is appointed by the head of the Judiciary Power. According to Article 2 of the code of procedures approved in 2016, this center is presided by one of the deputy heads of the Judiciary who is appointed by the head of the Judiciary. The word "deputies" is replaced in the current code of procedures which seems to be a positive change justified by the workload of the head of the Judiciary.

Medical affairs can also be dealt with in this council.

\subsubsection{DRCs for Women and Children Prisoners}

The branch of DRC for Women ${ }^{1}$ and Children Prisoners has three judges besides a supervisor as well as other members including the head of the Correction and Rehabilitation Center of Tehran Province and the head of Women's Prison.

After these branches were formed, social workers no longer had to refer to plaintiffs in order to obtain consent; rather, a subpoena was sent to them in order for them to attend the Branch of DRC in the prison and be talked to for their possible consent.

4. An Analysis and critique of legislative developments of the DRC regarding its composition, method of selection, membership conditions, and recusation

\subsection{Analysis and critique of the legislative developments of the council regarding the composition and selection of its members}

An analytical description of Article 3 of the DRC Act approved in 2008 and 2015

The Approved Act of 8/07/2008

${ }^{1}$ Approved in $17 / 12 / 2015$ 
Article 3. Each council shall have three permanent members and two alternate members and can have an office of its own to perform its duties. The chairman shall be proposed by the head of the council and appointed by the chief justice of the province or his deputy.

Article 4. One or more judges called the council's judge(s) shall hear the claims in each judicial branch in accordance with the provisions of this Law. The council's judge can simultaneously be in charge of performing the affairs of several councils.

Approved Act of 7/12/2015

Article 3. Each council shall have a head, two permanent members and one alternate member and, where required, it can have another person in charge of the office, who shall be proposed by the head of the branch and appointed by the chief justice of the province or his deputy.

Article 4. One or more judges called the council's judge(s) shall hear the claims in each judicial branch in accordance with the provisions of this Law.

\section{Conclusion: prediction of appointment of a head for the DRC beside the permanent members}

According to the current law, the head of the Judiciary or his representative is responsible for the selection of a head for the DRC and the issuance of his letter of appointments (Articles 5 to 5 of the law). Considering the history and rationale for the establishment of DRCs, the need for people's participation in Resolution of disputes between themselves, and implementation of the seventh principle of Constitution of the Islamic Republic of Iran as well as the quasijudicial nature of the council, the abovementioned change is not considered a positive change.

\subsubsection{Permanent Members, Alternate Members, and Office Secretary}

According to Article 3 of the DRC Act approved in 2015, each council has one head, two permanent members and one alternate member. While councils have three permanent members and two alternate members according to the beginning of Article 3 of the DRC Act approved in 2008. Article 3 of the DRC Act approved in 2015 adds that, if necessary, each council can have an office secretary proposed by the Head of the Judiciary and then appointed by the Chief Justice of the Province or his deputy. Article 3 of the DRC Act approved in 2008 also stipulates that each council can have an office with a secretary proposed by the head of the council and then appointed by the Chief Justice of the Province or his deputy. 
The change having occurred in this article is related to the office secretary for each council, who is proposed by the head of the judicial branch according to the current law; while the previous law deemed him or her to be proposed by the head of the council, which is an ambiguous term that can be used for the head of the DRCs in each province, the general director of DRCs in Iran, or the head of the Judiciary branch of each council in each province. However, this ambiguity has been resolved in the current law.

\subsubsection{Council Judge}

An Analytical description of Article 4 of the DRC Act approved in 2008 and that approved in 2015

Approved Act of 8/07/2008

Article 5. The council judge shall be appointed by the head of the Judiciary from among the employed judges, and the appointment letters of other members of the council shall be issued by the head of the Judiciary or the person appointed by him after they are approved.

Approved Act of 7/12/2015

Article 4. One or more judges called the council judge(s) hear the claims in each judicial branch in accordance with the provisions of this law.

Note 1- The Judiciary can appoint both employed and retired judges as the judges of the council.

The result is that the new law has predicted the use of retired judges to improve the performance of DRCs and reduce the burden of the employed judges.

\section{An Analysis and critique of legislative developments regarding the civil liability of councilors}

The purpose of civil liability of councilors is to compensate for the harm imposed to others by the councilors' acts or omission of acts. This does not mean that the loss is compensated in all cases; rather, it means that the person should be restored to their previous state. The criterion for civil liability is one's fault or negligence in the loss or damage to another person.

\subsection{Civil Liability of DRC Members}

Civil liability, which is part of civil rights, has its own specific foundations from various economic, industrial, and other aspects. The DRC is a new institution and the responsibility of 
its members should be clarified considering other laws. By councilors' fault is meant harmful acts committed by members of the council while they are doing their jobs. Intentional fault is a fault committed deliberately and knowingly to harm an individual, which does not differ between the Councilors and the judge or legal advisor, who will be deemed liable if they commit any intentional fault. Therefore, each of the members with an intentional fault has general liability according to Article 1 of the Civil Liability Law, and all members shall be deemed liable if they are faulty and violate the regulations while issuing any verdict or determining the level of damages incurred according to Article 1 of the Civil Liability Law and Principle 171 of the Constitution. However, they will not be personally liable if they make any unintentional mistake while investigating and issuing the verdict. Since the judicial system is in charge of creating the justice, it will be liable for the damage. An office manager who is in charge of administrative affairs of the council and is chosen by councilors will be liable for the damages or loss in cases of negligence or mistakes, according to Articles 1 and 11 of the Civil Liability Law unless he proves that the damage has resulted from deficiencies of the administrative system.

\section{5-2. Civil Liability due to the Decisions of the DRC Members}

Article 953 of the Civil Law defines fault as including negligence and trespass, which Articles 951 and 952 define as follows:" Trespass is violation of the permitted or conventional limits of others' property or rights, while negligence means to avoid doing an act which is necessary by convention or contract for protecting others' property". ${ }^{1}$

The concept of fault in the duties of DRC members is their doing any unconventional act forbidden by the law and regulations or their refusal to perform an act that is within their responsibilities based on the law or code of procedures, which makes the person liable if it leads to any damage or loss.

\section{An Analysis and Critique of legislative developments regarding the Boards Handling the Councilors' Violations}

An Analytical description of Article 34 and Article 4 of the DRC Act, approved in 2008 and 2015

Article 39 of the DRC Act, approved in 2008

${ }^{1}$ Jafari Langeroudi, Mohammad Jafar, Terminology of Law. Ganj-Danesh Publication, p. 162 
The Board Handling the Councilors' Violations includes a representative of the Disciplinary Court of Judges, the head of the DRC of the province, and the head of the Courts' Intelligence Protection Organization of the province.

Article 34 of the DRC Act, approved in 2015

The Board Handling the Councilors' Violations consists of a judge appointed by the Chief Justice of the province and head of the DRC and the head of the Courts' Intelligence Protection Organization of the province.

Note: The head of the Judiciary appoints the board to act for a three-year period and can reappoint them for another period.

The result is that it is better to use the Disciplinary Court of Judges' experience for handling the violations of the DRC members, so the previous law is preferred.

There is also a change in the combination of the members of the Board Handling the Councilors' Violations, such that one of the three members of the board who was a representative of the Disciplinary Court of Judges was replaced in the new law by a judge appointed by the Chief Justice of the province. In comparison, it seems that the previous board had a more special structure due to the special supervisory status of the Disciplinary Court of Judges. However, this law has focused more on the councilors' violations and has dealt with its instances in Article 35 and Article 36.

Article 38 of the previous law and Article 33 of the current law have stipulated that a head cannot change or fire a councilor, which assures them that they have no fault or negligence in doing their accepted duties, because the head of the DRC of the province could fire the members according to the previous regulation. Moreover, Article 38 of the previous law and Article 34 of the current law have specified the combination of the board and the representative of the Disciplinary court of judges was a member of the board according to the previous law, but was substituted by the Chief Justice in the current law. One case of members' fault is their actions resulting from their violation of the procedure for organizing the $\mathrm{DRC}$, the executive regulations, and related rules.

\section{Analysis and Critique of the legislative developments of the DRC in terms of proceeding jurisdiction and conflict of jurisdiction}


One of the most fundamental and important innovations of the 2015 Law is its change in the level of jurisdiction of DRCs, although the new law, like the previous law, divides the DRC's jurisdiction into the following two cases: 1) cases where the council has the authority to bring compromise between the parties to a dispute 2) cases in which the council must issue a verdict. Regardless of Article 8 which is the same as the 2008 law, Article 9 of the current law highlights significant changes. Article 9 of the DRC Act deemed councilors to be in charge of dealing with traffic-related violations, while such a responsibility was removed in Act 5 of the new traffic rule.

\subsection{DRCs' Jurisdiction in Dealing with Legal Affairs}

The local jurisdiction of each council corresponds with to its related judicial district, and each council's area of jurisdiction is specified by the head of the related judicial branch. In addition, special branches for compromise and reconciliation are to be formed possibly in courts if needed according to articles 8 and 11 of the current law.

Complaints, appeals and lawsuits predicted to be within jurisdiction of the Council under Article 9 of the Law are directly submitted to the Council, and the Judicial Officers are required to submit complaints under Section $(\mathrm{H})$ of this Article to the local council.

According to the executive regulations of Article 189 in the Third Economic, Social and Cultural Development Plan Code, these councils could issue pecuniary punishments up to about 50000 dollars or a sum of custodial sentence after converting imprisonment to pecuniary punishment up to 50000 dollars. Moreover, the councils had the jurisdiction to deal with offences punished for a period less than 91 days or deal with traffic violations requiring discretionary punishment (in compliance with Section 1 of Article 3 of the Law for Collecting Certain Government Revenues and Consuming them in Certain Cases, approved in 1994 and 1995). However, this rate was determined 6 times as much as this (up to 300000 dollars) in Article 9 if the previous law, which was very hard and even impossible for many families in our country to provide. Therefore, assigning such proceeding jurisdiction- contrary to the principle of presumption of innocence and denial of their freedom- to authorities with neither adequate knowledge nor the required qualifications in legal affairs equals to violation of the basic rights of the community, invasion to individual freedoms, and contradiction to the articles of Principle 36 of the IRI Constitution, according to which sentencing to punishment is only within the jurisdiction of the courts. It is surprising that the Guardian Council lawyers have 
approved this article, since according to Principle 36 of IRI Constitution ${ }^{1}$, the significance of penal affairs and the necessity of preventing and avoiding illegal violation of people's dignity, property and liberty involves that only competent courts sentence and execute punishments in accordance with the law; and since penal regulations, including substantive law and procedural law, are among mandatory laws related to public order and manifest governments' use of ownership in domestic law, hence it is not justifiable from the perspective of constitutional law to assign the execution of punishments to non-judicial institutions, and no place other than the court has been considered here for resolution of disputes.

\subsection{Conflict in jurisdiction of the DRC}

In cases of conflicts of local jurisdiction among the councils of one judicial district, the rule mentioned in Paragraph A of Article 15 must be applied, but if there is a conflict between the councils of a city or province, it is the court of appeal that will be in charge of resolving the dispute. Moreover, if there is a conflicts of jurisdiction between the councils of two different provinces, the Supreme Court shall resolve the dispute in accordance with the Note added to Article 27 of the Civil Procedure Code. However, the case can be submitted to the Supreme Court for determining the competent authority in accordance with Article 28 of the Civil Procedure Code if the council issues incompetency of non-court judicial authorities.

\subsubsection{Conflict in local jurisdiction and inherent jurisdiction}

Article 15 of the executive regulation of Article 189 of the Third Economic, Social and Cultural Development Plan Code stipulates that "if the council finds itself incompetent to resolve the issue, it shall submit the case to a competent judicial authority, notify the claimant to bring a lawsuit in a competent court in the case of civil affairs, and put to archives the case submitted to the council". This was followed by various problems to the point that some proposed that councils are parallel to general courts and set forth the need to resolve their conflicts of jurisdiction by a court of appeal and the Supreme Court (assuming councils as non-judicial courts). However, this issue was resolved in articles 15 to 17 of the previous law and Article 13 of the current law.

\section{Analysis and Critique of legislative developments regarding jurisdiction procedures}

\subsection{Jurisdiction procedures in the DRC}

\footnotetext{
${ }^{1}$ Principle 36 of IRI Constitution: punishment and its execution is only within the jurisdiction of a competent court and should be executed in accordance with the law.
} 
Proceeding in councils starts with an oral or written request. The oral request is written in the minute of the meeting and signed by the claimant or the applicant. The request should include first and last names, addresses of parties to the dispute, the request subject, and the claimant's reasons and evidence (articles 18 and 19).

According to Article 10 of executive regulations of the Third Economic, Social and Cultural Development Plan Code, Article 21 of previous law, and Article 19 of the current law, proceeding in the council does not follow the procedures of the Civil Procedure Code. The council summons the parties as it requires, hears what they say, writes a summary of it and has the parties sign it. Therefore, inviting the parties and communicating judicial papers, which are the most important procedures in the proceeding code and delay the proceeding process, have been resolved appropriately by the councilors and have thus accelerated the proceeding process. In addition, it will not be necessary to comply with the minimum time interval between the summon date and the meeting date.

According to Article 23 of the previous law and Article 22 of the current law, local examinations and investigations cannot be delegated to another, and the council can assign the local examinations or investigations to a councilor only.

\section{8-2. Decision making in the DRC}

According to Article 299 of the Proceeding Code of the General and Revolutionary Courts in Civil Matters, "If the court's decision is on the nature of the dispute and stops it in part or in whole, it is called judgment; otherwise it is referred to as writ".

\subsubsection{How to Issue a Judgment}

The judgment of the DRC, along with that of other judicial authorities, has been considered in Note 1 of Article 774 in the modified Criminal Procedure Code of 2015 as a judgment which can be requested for being contrary to the explicit religious law ${ }^{1}$. Also, according to Article 30 of the Act of 2015 about the person convicted by the judge's verdict after consultation with the

\footnotetext{
${ }^{1}$ Mohseni, Hassan, Effective execution of the verdict and the execution of financial conviction. Tehran, Enteshar Joint Stock Company, p.2015
} 
councilors, one can ask for the implementation of Article 3 of the Execution of Financial Convictions Act of 2015.

\subsubsection{Issuing a writ}

According to Article 299 of the Proceeding Code of the General and Revolutionary Courts in Civil Matters, whenever a court make a decision that is not related to nature of the dispute or does not resolve the dispute, it is called a writ.

However, if in a dispute, one of the parties claims that the court is not competent to resolve the dispute according to the law, the decision made by the court in this regard is a "writ", rather than a warrant.

\section{8-2-3. Corrective Verdict}

Article 28- The DRC of 2016 stipulates: "Whenever a writing mistake occurs while writing a verdict, such as the omission or addition of a word, or a mistake in calculation, the Judge of the Council shall correct the verdict personally or on a request from the beneficiary and communicate the issued verdict to the parties until the verdict is objected to. It is forbidden to submit a copy of the main verdict without the corrected verdict".

Article 32 of the old DRC Law and Article 28 of the new DRC Law stipulate: Whenever a writing mistake occurs while writing a verdict, such as the omission or addition of a word, or a mistake in calculation, the Judge of the Council shall correct the verdict on a request from the beneficiary and communicate the issued verdict to the parties until the verdict is objected to.

\section{8-2-4. Corrective Report or Compromise Letter}

According to Article 24 of the current DRC Law and Article 25 of the previous DRC Law, the decisions of the Dispute Resolution Council have a corrective aspect and this council is unable to issue a verdict. The corrective report shall be issued in accordance with the authority of the council if an agreement is reached between the parties and communicated to the parties after approved by the judge of the council. However, if the council's mediation goes without a compromise between the parties, the subject of the dispute will be written in a minute of a meeting to be submitted to a judicial authority. Unlike the council, the judge of the council can issue a verdict either in person or in absentia. The issued verdict can be objected to within 20 
days, while the corrective report is not objectionable. In other words, Note 1 of Article 27 of the current law and Article 30 of the previous law are definite.

The corrective report of the council is also executed by the enforcement unit in accordance with Note 1 of Article 27 of the current law and Article 30 of the previous law as ordered by the judge of the council.

If a lawsuit is within the jurisdiction of the Council, the Council can set up a compromise letter and issue a corrective report and the parties to the dispute, particularly the defendant, have the right to object to the proceedings of the Council according to Note under Article 8. This is an intrinsic jurisdiction and cannot objected by the parties to the dispute. However, if the Council does not have intrinsic jurisdiction in a certain case, it can simply set up a Compromise Letter, but cannot submit a corrective report to the council's judge, and the case must be submitted to the general court of the judicial district. In addition, in these cases, the plaintiff may resort to the note under Article 8 and stop the proceedings in the Council. According to Article 24 of the adopted law of 2016: if the parties reach a compromise in issues raised under Article 8 of the law, a corrective report will be issued, confirmed by the judge of the council, and notified to the parties. Article 15 of the Law adopted in 2016 and Article 16 of the previous law stipulate: "the unwillingness of the other party to a lawsuit or complaint against the proceedings of the council in issues brought in the note under Article 8 of the law may be declared or submitted in writing to the Council with the presence of that person or their attorney.

\section{8-3. Objection to decisions made in the DRC}

\section{8-3-1. Protest}

In Note 2 under Article 18 of the present law, the provisions relating to the issuance of verdicts, protest, appeals and costs of proceedings are excluded from the provisions of this article and are subject to this law. According to Article 29 of the previous law, a person convicted while absent in the proceedings is entitled to protest the issued judgment by default within 20 days from the date of actual verdict notification. This protest should be considered and heard by the judge.

The judgments by default have been considered as definite and final, and contrary to the obvious legal principles that are considered for such judgments, this right has been ignored in that article. Obviously, notification in Article 18 of the Code includes legal and actual notices.

\section{8-3-2. Asking for appeals}


According to Article 31 of the previous law, all of the issued judgments based on article (9) and (11) of this law shall be subject to appeal within twenty days from the date of notification. The authority that can rejudge the judgments of the Council will be the Council' Judge, whose judgments can in turn be rejudged by the General Court of that judicial district. If the appeal authority rejects the issued verdict, it will personally issue a new verdict, and according to Article 27 of the present law, all issued verdicts under Article (9) of this Law shall be subject to appeal within twenty days from the date of notification. The appeals authority for the verdicts issued by the Judge of the Council shall be the general legal or penal court of that judicial district, depending on the case. If the appeal authority rejects the issued verdict, he will personally issue a new verdict. This new verdict will be the final verdict, but the case will be submitted to a competent authority if the case is to be dealt with by another competent authority. The innovation of the current law emphasizes that if the council's verdict (which has been issued by the judge after consultation with the members of the Council) is rejected due to the lack of competence, the appeal court (the general court of law or the criminal court) shall, after a substantive hearing, issue a verdict, and this verdict will be considered the verdict of the first authority and can be appealed in the appeal court of the province (Note 2 under Article 27). In other words, if that verdict is rejected in the General (Legal or Criminal) Court due to lack of competence and proceedings are within the jurisdiction of these Tribunals (Article 27), this court will deal with the dispute in order to reduce the time and expenses of the parties to the dispute contrary to the proceedings code of the court of appeals (articles 943, 253 and 353 of the Civil Procedure Code and its judgment shall be regarded as the verdict of the first court and is subject to appeals in accordance with the principle of substantive proceedings. The general court of law or the criminal court will not consider only what has been appealed, and this is contrary to the missing principles of the appeal of the verdicts, reflecting the position of the DRC.

Now the question is what is the relationship between the "DRC" and the "Legal Criminal Court" or "Criminal Court Two" in terms of competence, based on the above analysis that the DRC and the judge identified it as the lower judicial authority with a relative and specific jurisdiction. According to articles 31 to 51 of the council law, these councils act as does the General Court in dispute resolution and, if there is a conflict between them, the latter will be the competent authority. Also, the verdicts of the council judge can be appealed in this court (Article 27 of this law). The judge of the council shall have exclusive jurisdiction to deal with criminal affairs as well. Therefore, there is no doubt that the council and its judge will not be able to deal with 
claims beyond their own specific relative and substantive jurisdiction, so that, if a claim is outside the jurisdiction of the Council, this authority is obliged to ask the general court to deal with it.

\section{8-3-3. Appealing to the Supreme Court}

The verdicts of the DRC cannot be appealed to the Supreme Court ${ }^{1 "}$. From the provisions of Note 2 under Article 21 of the DRC Law approved in 2008 and Article 31 of this law, and considering articles 367 and 368 of the Civil Proceeding Code adopted in 2000, we can infer that appealing to the Supreme Court can occur only in the case of verdicts issued by courts rather than DRCs. It was also explained earlier that appealing to the Supreme Court is an extraordinary way of objecting to the judgments issued by courts and only verdicts explicated in the law may be appealed to the Supreme Court. Therefore, the legislator has explicitly stated unappealability of the verdicts issued by the lower and appeal courts in articles 367 and 368 of the Civil Procedure Code. Therefore, we should suffice only with exceptional cases and consider appealable only those judgments specified by the legislator.

It seems that, considering the principle of unappealability of these verdicts in the Supreme Court and the legislator's not specifying to such in the case of the verdicts issued by the DRCs, we can say that the verdicts issued by the DRCs cannot be appealed to the Supreme Court. This argument is in accordance with the legal articles in the DRC affairs, but it does not seem to be in accordance with the existing laws, legal norms and principles of justice and fairness, because although the DRC Law and Regulations have not mentioned the appealability of these verdicts, appealability is not considered in the case of non-financial claims brought in councils which are within their intrinsic jurisdiction.

It seems that, considering the principle of unappealability of these verdicts in the Supreme Court and the legislator's not specifying to such in the case of the verdicts issued by the DRCs, we can say that the verdicts issued by the DRCs cannot be appealed to the Supreme Court. This argument is in accordance with the legal articles in the DRC affairs, but it does not seem to be in accordance with the existing laws, legal norms and principles of justice and fairness, because although the DRC Law and Regulations have not mentioned the appealability of these verdicts, it contradicts the justice and fairness and legal logic to consider it unappealable when it contradicts the law or jurisprudence.

${ }^{1}$. Advisory opinion of the General Legal Administration of the Judiciary Power: $22 / 11 / 2014$ 


\section{8-3-4. Retrial}

In the DRC Law, the legislature has not considered the possibility of retrial of the verdicts issued by the DRCs or the council's judge, although this is possible in terms of legal logic, because the verdicts issued by this authority do not differ in nature from the judgments issued by the general courts or courts of appeal; besides, the general and comprehensive nature of the Civil Procedure Code justifies this possibility in legal affair, meaning that a law put forward by the legislature as a general rule can be extended to other similar cases with that particular subject. However, the basis for this prescription is the characteristic of the claim brought in the council. The fact is that the DRC can deal with affairs that are in fact within the jurisdiction of the General Court and are relatively legally put within the jurisdiction of the Council or the Council's judges, and this relative jurisdiction does not preclude the verdicts of this authority from the possibility of retrial. This can be inferred from Article 18 of the DRC Law: "the judge of the Council shall hear and judge the claims in accordance with the principles and rules of the Civil Procedure Code and the Criminal Procedure Code". Article 19, which stipulates: "the Council's proceedings is not based on the procedures of the Civil Procedure Code" does not preclude the retrial possibility, because this cannot be regarded as the procedures of the proceeding code ${ }^{1}$. Accordingly, the retrial of the verdicts issued by the council and the judge of the council occurs as it has been raised in the Civil Procedure Code and particularly Article 624.

Regarding the possibility of using extraordinary ways of protesting the verdicts, the current law of the Dispute Resolution Council is silent, and it is subject to the provisions of the Civil Procedure Code, and retrial is logically possible in accordance with the provisions of articles 18 and 19 of the DRC. However, retrial of the corrective reports of councils is not relevant due to its scope of jurisdiction.

\section{Conclusion}

- As noted above, the DRCs were established to reduce the number of incoming judiciary cases and increase people's participation in the Resolution of disputes.

- DRCs have reduced the number of cases brought to courts in most provinces and cities by 50 percent. According to some lawyers, these statistics are not realistic. Regardless of whether these statistics are precise or not, what is important is that the DRCs might never face the problems that they are now facing if such an institution had been approved within

\footnotetext{
1 . Mohseni, Hassan. The concept of proceeding principles and their interpretive role, and how to distinguish these principles from the proceeding procedures, Journal of Attorneys Center, Issues 13 and 23, spring and summer 2006, pp. 99-131
} 
the framework of the Constitution and the existing ordinary laws and its required mechanisms about its execution had been predicted before its actual execution. Under such conditions, the councils (given the capabilities of this institution) could actually solve a problem of the Judiciary instead of becoming a problem for it.

- We can infer from the above-mentioned points that the DRCs, besides their disadvantages, have advantages over judicial courts in dealing with claims. Bringing an action in the Council does not follow the procedures of the Criminal Procedure Act, including the detailed procedures regarding how to bring a lawsuit, how to enter a complaint, complying with certain conditions when writing a complaint, notification of judicial papers to the parties to a dispute, attending the hearing meeting, and so on, while proceedings in DRCs are free of these tedious procedures. This is why the cases dealt with in councils lead to issuance of verdicts much faster than those dealt with in courts. In addition, dealing with disputes at the DRCs is free of charge at all stages, including the stage of bringing the lawsuit and asking for appeal, which has encouraged people to bring more actions in these institutions.

- The formation of DRCs has been followed by a considerable reduction in the number of people's appeals to courts, and many of their claims either have led to reconciliation and compromise in these councils or have been resolved by individuals selected from among the people themselves.

- Although the DRC was established with the two goals of reducing people's appeals to courts and increasing people's participation, ambiguity in Article 189 has in practice created challenges for this council. The current status may imply that the legislator has ignored the obvious legal and religious principles on the pretext of achieving the above goal.

- Many of the drawbacks of this article and its code of procedures arise from the assignment of preparation of regulations to authorities other than the parliament, which has reduced the accuracy and supervision, and considering the process of preparation of the code of procedures, it has created the ambiguity of whether the complaints about that code of procedures must be dealt with in the Court of Justice or not. In other words, it is unclear whether this code of procedures is approved by the Cabinet to be dealt with by the Administrative Justice Court, or has come from the circulars and approved acts of the Judiciary, which cannot be dealt with in the Administrative Justice Court. If it has come from the Judiciary, which authority can handle complaints from the circulars and approved acts of the Judiciary?

- One of the serious challenges for DRCs is the involvement of ordinary unspecialized people in the demanding job of judgment, which is obviously contrary to the Constitution and our common law and is a clear violation of the rights of citizens who necessarily refer to the councils to achieve their rights. Moreover, referral to the councils, which is contrary to the principle of general jurisdiction of courts as the chief authority for bringing justice, is itself a fundamental challenge that even contradicts the goal of forming such councils.

- Historical records are often used in expressing the objectives of the council (Houses of Equity, arbitration councils and similar cases in other countries, in particular from Article 189 of the Third Development Plan Code), but these objectives are set regardless of Article 1 of the council Law (approved in 2008) and lead to illegal expectations from the executor. In addition, some of such goals are often among the requirements or results of the Council, which causes some kind of confusion. Thus, according to Article 1 of the Council Law, the goal of councils is to bring compromise in legal financial claims under Paragraphs 1 and 2 of Article 11 and Article 12 of the Law) and to perform quasi-administrative activities under Paragraphs 3 and 4 of Article 11 and Article 9 of the law, and finally to issue a verdict in case no compromise is reached (unlike courts which essentially issue verdicts (Article 3 of the Civil Procedure Code). 
- This institution is not new. According to Article 189 of the Law of the Third Plan Code of the Development of the Islamic Republic of Iran, it is a combined and reformed institution using the laws of the Houses of Equity and arbitration courts, which has taken the current form under the law approved in 2016.

- Councils need a coherent judicial and administrative structure.

- The innovations of the DRC Act of 2016 are as follows:

1. A change in the number of the Councilors and its appointers: Article 3 has reduced the number of councilors to two main members and one alternate member, and it must be proposed by the head of the Judiciary of the province and then appointed by the head of the center for council affairs

2. The use of retired judges as judges of the council has been foreseen in the note under Article 4.

3. Neither the DRC nor its judge is allowed to issue any decree; they can only issue corrective reports

4. The implicit acceptance of the council's competence owing to lack of citation in the first session is just limited to Article 8 and the competence of the council rather than the council's judge.

5. If, in the event of appealing the judge's decision, the general court of law or criminal court 2 finds the council to lack competence, and the cases are within the jurisdiction of these judicial authorities, that court will deal with the case after violating the council's verdict, and shall issue a verdict which will be considered the first court's verdict to be subject to appeal by the appeals court of the Province (Article 27); a procedure which is contrary to Article 352 of the Civil Procedure Code and the position of the appeal authority and the principle of limitation of the jurisdiction of the appeal. However, it seems justifiable from the perspective of the economic analysis of law.

6. The possibility of the use of Article 3 of the Law on the Implementation of Financial Convictions for Council Verdicts and not the Corrective Reports has been predicted in in Article 30 of this Law.

7. Arrangements and references for councilors' violations have been foreseen from Article 33 on.

8. Work experiences as a member of the Council for three years has reduced the number of apprenticeship for power of attorney, judgment and official expert of courts by 50 percent.

9. Article 41 of this law stipulates that the procedure for dealing with cases that have not led to verdicts in councils shall be subject to this law.

10. In addition to imprisonment, the council is not authorized to issue a whip order.

11. Although the law remains silent regarding the DRCs, it has limited their jurisdiction to bringing reconciliation and compromise in Note 2 of Article 9.

\section{References}

A) Books :( Persian-Arabic)

1) Azar Noush, Azartash (2011). Contemporary Arabic-Persian Dictionary.

2) Abhari, Hamid; Barzgar, Mohammad Reza (2012). Civil Procedure Code (1), Babolsar, Mazandaran University Publication.

3) Entezari Najafabadi, Alireza (2016). Civil Liability due to Environmental Damages, Tehran: Morkhatab Publication.

4) Jalali, Seyyed Mehdi (2013). Execution of Civil Judgment, Tehran: Khorsandi, $1^{\text {st }}$ ed.

5) Shah Heydaripoor, Mohammad Ali (2013). Civil Procedure Code, Competence of 
Courts, Tehran, ADAK.

6) Ghafouri, Ali (2018). Way of Living from the Perspective of Imam Sajjad (A.S), Office for Publication of Islamic Culture.

7) Yousefzadeh, Morteza (2013). Civil Procedure Code, Tehran, Enteshar Joint Stock

Company.

B- Articles / Journals

8) Mohseni, Hassan (2016). The Position of the DRC and how to Protest its Judgments, Legal Journal of Justice.

9) Nikkhooy Monfared, Reza (2013). A Practical Review and Critique of the DRC Act.

10) Farahmand, Mojtaba (2011). Legal Foundations of the DRC, Dadrasi Publication, Issue 78, January.

11) Gorji, Abolghasem. Legal Articles (2 Volumes) - Tehran University Press.

C- Dissertations

12) Zera'ti, Mojtaba (2016). A Review and Critique of the DRCs of Kashan in Penal affairs, master's thesis in criminal law, Islamic Azad University of Naraqh.

13) Javadi, Khashayar (2011). A Review of the Nature of the Issues to be Referred to the DRC, master's thesis in private law, Islamic Azad University of Naraqh.

D- Rules and Regulations, Advisory Opinions and By-laws

14) The DRC Code

15) The Third Economic, Social and Cultural Development Plan Code of the Islamic Republic of Iran

16) - Advisory Opinion No. 41/95/7, 4/4/2016 of the Legal Department of the Judiciary, quoted by the Official Newspaper, 1994, No. 20800, Special Letter No. 887, Saturday, August 6, 2016 